\title{
PENGARUH EKSTRAK ETANOL JAMUR LINGZHI (Ganoderma lucidum) TERHADAP KADAR HDL (High Density Lipoprotein) PADA TIKUS DISLIPIDEMIA
}

\section{EFFECT OF ETHANOLIC EXTRACT OF LINGZHI FUNGUS (Ganoderma lucidum) ON HDL (High Density Lipoprotein) LEVEL IN DISLIPIDEMIC RATS}

\author{
Pritalia Ratra Furi dan Arifah Sri Wahyuni* \\ Fakultas Farmasi, Universitas Muhammadiyah Surakarta \\ arifah_sriwahyuni@yahoo.com
}

\begin{abstract}
ABSTRAK
Jamur lingzhi (Ganoderma lucidum) termasuk dalam family Polyporaceae yang diketahui memiliki banyak manfaat untuk pengobatan. Penelitian ini merupakan penelitian eksperimental (pretest-postest control group design) dengan rancangan acak lengkap pola searah dan ditujukan untuk mengukur pengaruh ekstrak etanol Ganoderma lucidum pada tingkat HDL pada tikus dislipidemia. Terdapat 4 kelompok perlakuan masing-masing kelompok terdiri dari 5 ekor tikus yaitu kelompok kontrol normal, kontrol negatif, dosis 1 dan dosis 2. Kelompok kontrol normal diberi pakan standar sedangkan kelompok kontrol negatif, dosis 1 dan dosis 2 diberi diet tinggi lemak selama 4 minggu dan ekstrak etanol jamur lingzhi masing-masing 200 mg/kgBB (dosis 1) dan $400 \mathrm{mg} / \mathrm{kgBB}$ (dosis 2) selama 2 minggu secara per oral. Data yang diperoleh dianalisis dengan uji Anava taraf kepercayaan 95\%. Hasil penelitian menunjukkan bahwa ekstrak etanol jamur lingzhi (Ganoderma lucidum) dosis $200 \mathrm{mg} / \mathrm{kgBB}$ dan $400 \mathrm{mg} / \mathrm{kgBB}$ tidak mampu meningkatkan kadar HDL pada tikus dislipidemia
\end{abstract}

Kata Kunci: Dislipidemia, kadar HDL, ekstrak etanol jamur lingzhi (Ganoderma lucidum)

\section{ABSTRACT}

Ganoderma lucidum is a medicinal fungus belonging to the Polyporaceae family which has been known has a lot of benefits effect for therapy. One of them that has not been explored is antidislipidemia by increasing the HDL level. This study was conducted to measure the effect of ethanolic extract Ganoderma lucidum on HDL level in dyslipidemic rats. The research was an experimental (pretest-postest control group design) with one way complete random design. There were 4 groups of treatment, each group consisted 5 rats. They were normal control, negative control, dose 1 and dose 2 groups. Normal control group was treated with standard diet, negative control was treated with high lipid diet whereas dose 1 and dose 2 group was treated with high lipid diet and orally ethanolic extract Ganoderma lucidum $200 \mathrm{mg} / \mathrm{kgBW}$ and $400 \mathrm{mg} / \mathrm{kgBW}$ dose. Data were analized statistically with One Way ANAVA.The result showed that ethanolic extract Ganoderma lucidum at the dose of 200 and $400 \mathrm{mg} / \mathrm{kg} \mathrm{BW}$ could not increase HDL level in dyslipidemic rats.

Key words: Dislipidemia, HDL level, ethanolic extract Ganoderma lucidum

\section{PENDAHULUAN}

Dislipidemia adalah terjadinya kelainan metabolisme lipid, baik peningkatan maupun penurunan fraksi lipid dalam plasma. Kelainan fraksi lipid yang utama adalah kenaikan kadar kolesterol total, kolesterol LDL, Lipoprotein a, kenaikan kadar trigliserida serta penurunan kadar HDL (Ballantyne et al, 2009). Tingginya kadar lemak (lipid) dalam darah dapat menyebabkan terjadinya aterosklerosis, yang ditandai dengan terdapatnya ateroma pada bagian intima arteri yang berisi kolesterol, zat lipoid, dan lipofag (Suyatna, 2008). Perkembangan lebih lanjut dari aterosklerosis ini akan menimbulkan komplikasi pada organ target diantaranya jantung dan otak (Pinzon dan Asanti, 2010). Salah satu penegak diagnosis terjadinya dislipidemia adalah rendahnya kadar HDL dalam darah. Kolesterol HDL bersifat protektif, berfungsi membawa kelebihan kolesterol ke hati untuk diproses dan diekskresikan bersama cairan empedu (Barter, 2005). Rendahnya kadar HDL dalam darah dihubungkan dengan peningkatan resiko penyakit jantung koroner (PJK) karena kadar HDL yang rendah akan memacu munculnya proses atherogenik (pembentukan plak di dinding pembuluh darah arteri) (Pinzon dan Asanti, 2010). Studi epidemiologis menunjukkan bahwa setiap peningkatan $1 \mathrm{mg} / \mathrm{dL}$ kadar kolesterol HDL menurunkan risiko PJK 2\% pada laki-laki dan 3\% pada 
perempuan dan hal tersebut tidak dipengaruhi oleh kolesterol LDL (Kostner, 2002).

Berbagai usaha alternatif dalam mengobati dislipidemia telah banyak dilakukan, antara lain dengan menggunakan obat-obat tradisional. Salah satu obat tradisional tersebut adalah jamur lingzhi (Ganodema lucidum). Jamur lingzhi mengandung triterpenoid, sterol, polisakarida, protein, peptida, asam amino, adenosin, asam oleat, vitamin dan mineral (Paterson, 2006). Berdasarkan penelitian yang dilakukan oleh Tong dan Choong (2006) menunjukkan bahwa pemberian 0,1\% serbuk Ganoderma lucidum selama 5 bulan pada tikus yang dibebani diet tinggi kolesterol dapat menurunkan kolesterol total (TC), trigliserida (TG), kolesterol LDL serta menaikkan kolesterol HDL. Penelitian lain menunjukkan pemberian polisakarida Ganoderma lucidum dengan dosis $200 \mathrm{mg} / \mathrm{kgBB}, 400 \mathrm{mg} / \mathrm{kgBB}$ dan $800 \mathrm{mg} / \mathrm{kgBB}$ dapat menurunkan kolesterol total, trigliserida, kolesterol LDL, dan meningkatkan kolesterol HDL pada tikus hiperlipidemia (Chen et al, 2005). Selain itu, hasil penelitian Yang et al (2002) menunjukkan bahwa pemberian biopolymer Ganoderma lucidum dengan dosis $100 \mathrm{mg} / \mathrm{kgBB}$ selama 4 minggu mampu menurunkan kolesterol total, trigliserida, kolesterol LDL, fosfolipid, dan meningkatkan kolesterol HDL pada tikus hiperlipidemia.

Boh et al (2007) melaporkan bahwa senyawa triterpenoid yang terkandung dalam jamur lingzhi (Ganoderma lucidum) memiliki efek hipokolesterolemia. Mekanisme hipokolesterolemia triterpenoid melalui aktivasi PPAR-a (Jia et al, 2011). Francis et al. (2003) menyatakan bahwa aktivasi PPAR- $\alpha$ berkontribusi langsung dalam peningkatan kadar HDL dalam darah. Senyawa terpenoid larut dalam pelarut organik dan minyak (Williamson et al, 1996). Salah satu pelarut organik yang dapat digunakan adalah etanol. Menurut Hayati dan Halimah (2010) senyawa triterpenoid dapat terlarut dalam pelarut etanol. Penggunaan ekstrak etanol jamur lingzhi sebagai hipolipidemik dilihat dari peningkatan kadar HDL belum dibuktikan secara ilmiah. Oleh karena itu, perlu dilakukan pembuktian secara ilmiah tentang pengaruh ekstrak etanol jamur lingzhi (Ganoderma lucidum) terhadap kadar HDL pada tikus dislipidemia.

\section{METODE PENELITIAN}

\section{Kategori dan Rancangan Penelitian}

Penelitian ini termasuk jenis penelitian eksperimental (pretest-postest control group design) dengan rancangan acak lengkap pola searah (RAL).

\section{Alat:}

Spektrofotometer (Stardust), timbangan analitik, timbangan hewan uji, vortex, spuit injeksi, jarum per oral, scalpel, sentrifugasi, mikropipet, ependorf, alat-alat gelas.

\section{Bahan:}

Tikus putih jantan galur wistar dengan berat badan 100-200 gram yang berumur 2-3 bulan, jamur lingzhi, etanol 50\%, alkohol, akuades, pakan standar, kuning telur ayam, mentega, lemak sapi, PTU 0,05\%, reagen $\mathrm{HDL}$ presipitan, reagen kolesterol.

\section{Jalannya Penelitian \\ Determinasi Tanaman}

Determinasi dilakukan di Laboratorium Farmakognosi Bagian Biologi Farmasi Universitas Gajah Mada Yogyakarta.

\section{Pembuatan Ekstrak Etanol Jamur Lingzhi}

Sediaan uji dibuat dengan cara maserasi yaitu simplisia jamur lingzhi seberat $100 \mathrm{~g}$ dimasukkan dalam bejana kemudian ditambahkan 75 bagian larutan penyari etanol $50 \%$ (75 bagian dari $1000 \mathrm{~mL}$ hasil penyarian yang dikehendaki) yaitu sebanyak $750 \mathrm{~mL}$, ditutup dan dibiarkan selama 3 hari terlindung dari cahaya, sambil diaduk sesering mungkin supaya kontak antara simplisia dengan larutan penyari (etanol) merata. Setelah itu disaring dan ampasnya diremaserasi sampai mendapatkan 100 bagian yaitu sampai mendapatkan $1000 \mathrm{~mL}$. Sari yang telah didapatkan kemudian diuapkan dengan cara pemanasan tidak langsung yaitu dengan cara dipanaskan di atas penangas air dengan cawan porselin dengan suhu $60^{\circ} \mathrm{C}$ sampai terbentuk masa kental. Selanjutnya, ekstrak kental yang diperoleh ditambahkan amilum manihot secukupnya kemudian dikeringkan dalam oven hingga didapatkan ekstrak kering jamur lingzhi.

\section{Pembuatan Tikus Diet Tinggi Lemak}

Tikus dibuat dislipidemia dengan diberikan diet tinggi lemak. Diet tinggi lemak yang digunakan terdiri dari pakan tinggi lemak dan emulsi. Pakan tinggi lemak dibuat dengan cara mencampur $300 \mathrm{~g}$ pakan standar, $25 \mathrm{~g}$ lemak sapi (dilelehkan), $50 \mathrm{~g}$ kuning telur, dan $100 \mathrm{~g}$ mentega yang telah dicairkan kemudian dioven sampai pakan kering. Selain itu tikus juga diberikan emulsi. Komposisi emulsi terdiri dari $5 \mathrm{~g}$ lemak sapi; $10 \mathrm{~g}$ kuning telur; $7,5 \mathrm{~g}$ gom arab; dan air sampai 100,0 mL. Emulsi dibuat dengan memanaskan lemak sapi (gajih) agar diperoleh minyak, kemudian dibuat korpus emulsi dengan mencampur seluruh bagian minyak sapi dan kuning telur kemudian ditambah air sebanyak $11,25 \mathrm{~mL}(1,5 \mathrm{x}$ berat 
gom). Setelah terbentuk korpus emulsi kemudian ditambah air hingga volume $100 \mathrm{~mL}$. Emulsi diberikan setiap hari selama 2 minggu dengan dosis $2 \mathrm{~mL} / 200 \mathrm{gBB}$ dan selalu dibuat baru. Penetapan dosis diet lemak tinggi dilakukan melalui uji pendahuluan menggunakan 2 kelompok perlakuan. Kelompok pertama (kontrol normal) diberikan pakan standar sedangkan kelompok kedua (kontrol negatif) diberikan pakan tinggi lemak dan emulsi dengan dosis $2 \mathrm{~mL} / 200$ gBB. Masing-masing kelompok diukur kadar HDL pada awal dan 2 minggu setelah perlakuan. Selanjutnya, data kadar kolesterol HDL yang diperoleh di analisis dengan uji $T$ tidak berpasangan (Unpaired $T$ test) dan uji $\mathrm{T}$ berpasangan (Paired $T$ test).

\section{Penetapan Dosis}

Berdasarkan penelitian Yang et al (2002)

pemberian biopolymer Ganoderma lucidum $100 \mathrm{mg} / \mathrm{kg}$ selama 4 minggu mampu menurunkan kadar kolesterol total, kolesterol LDL, trigliserid, fosfolipid, serta menaikkan kolesterol HDL pada tikus hiperlipidemia. Mengacu penelitian tersebut maka pada penelitian ini digunakan peringkat dosis pemberian ekstrak etanol jamur lingzhi 200 dan $400 \mathrm{mg} / \mathrm{kgBB}$ selama 2 minggu (14 hari) pada tikus dislipidemia.

\section{Perlakuan Hewan Uji}

Dua puluh (20) ekor hewan uji (tikus) diadaptasikan terlebih dahulu dengan diberi pakan standar dan minum air selama 3 hari. Hewan uji dibagi menjadi 4 kelompok dengan masing-masing kelompok terdiri dari 5 ekor tikus. Pemberian perlakuan pada masingmasing kelompok yaitu:

Kelompok I: diberi pakan standar. Kelompok II: diberi diet tinggi lemak, PTU $0,05 \%$ dan akuades ad libitum. Kelompok III: diberi diet lemak tinggi, PTU $0,05 \%$ ad libitum dan sediaan ekstrak etanol jamur lingzhi dosis $200 \mathrm{mg} / \mathrm{kg}$ BB secara per oral. Kelompok IV: diberi diet lemak tinggi, PTU 0,05\% ad libitum dan sediaan ekstrak etanol jamur lingzhi dosis $400 \mathrm{mg} / \mathrm{kgBB}$ secara per oral.

Diet lemak tinggi diberikan setiap hari selama 4 minggu terdiri dari pakan tinggi lemak dan emulsi dengan dosis $2 \mathrm{ml} / 200$ gram BB tikus. Pengukuran kadar HDL dilakukan pada waktu: sebelum diberi diet lemak tinggi, 2 minggu (hari ke-14) setelah pemberian diet lemak tinggi, 2 minggu (hari ke-28) setelah perlakuan ekstrak etanol jamur lingzhi.

\section{Uji Penetapan Kadar HDL}

Kadar kolesterol HDL dianalisis dengan menggunakan metode CHOD PAP (Cholesterol
Oksidase Phenol Aminoantipyrin). Prinsip metode ini adalah kolesterol esterase menghidrolisis ester kolesterol dan $\mathrm{H}_{2} \mathrm{O}_{2}$ (peroksida) dibentuk dari kolesterol dalam proses oksidasi enzimatik dari kolesterol oleh kolesterol oksidase. Selanjutnya, $\mathrm{H}_{2} \mathrm{O}_{2}$ bereaksi dengan 4-aminoantipirin dan phenol dengan katalisator peroksidase membentuk quinonimine yang berwarna (Sidhi, 1991). Reaksinya sebagai berikut:

Kolesterol ester $+\mathrm{H}_{2} \mathrm{O} \stackrel{\mathrm{CHE}}{\longrightarrow}$ kolesterol + asam lemak

Kolesterol $+\mathrm{O}_{2} \stackrel{\mathrm{CHO}}{\longrightarrow}$ kolesterol-3-one $+\mathrm{H}_{2} \mathrm{O}_{2}$ $\mathrm{H}_{2} \mathrm{O}_{2}+$ phenol + 4-aminoantipyrin $\stackrel{\mathrm{POD}}{\longrightarrow}$

quinoneimine (merah)

Sebelumnya, serum direaksikan dahulu dengan reagen HDL presipitan. Prinsipnya kilomikron, VLDL dan LDL akan diendapkan oleh HDL presipitant. Kolesterol HDL tetap berada dalam supernatan kemudian diuji sebagai sampel dengan menggunakan reagen CHOD-PAP. Sebanyak 200 $\mu \mathrm{L}$ serum dicampurkan dengan $500 \mu \mathrm{L}$ reagen $\mathrm{HDL}$ presipitant kemudian diinkubasi pada suhu ruangan selama 15 menit. Setelah itu, dilakukan sentrifugasi pada 2500-3000 rpm sampai didapat supernatan jernih yang siap untuk dianalisis. Pembacaan absorbansi dilakukan dengan cara direaksikan dengan $100 \mu \mathrm{L}$ supernatan ditambahkan pereaksi kolesterol CHOD-PAP sebanyak $1000 \mu \mathrm{L}$. Campuran tadi dikocok dan diinkubasikan selama 5 menit pada $37^{\circ} \mathrm{C}$ kemudian dibaca absorbansinya pada $\lambda 546 \mathrm{~nm}$ dengan blangko reagen yang ditambah dengan akuades.

\section{Analisis Data}

Kadar kolesterol HDL (mg/dL) dihitung dari absorbansi sampel dibagi oleh absorbansi standar kemudian dikalikan dengan konsentrasi standar. Data kadar kolesterol HDL yang diperoleh dianalisis dengan uji statistik Kolmogorov-Smirnov dan uji homogenitas (Levene Test). Data terdistribusi normal dan homogen maka dilanjutkan dengan analisis variansi (ANAVA) karena menunjukkan perbedaan bermakna diantara kelompok perlakuan maka dilanjutkan dengan uji Post hoc dan uji T berpasangan (paired T test).

\section{HASIL DAN PEMBAHASAN \\ Uji Pendahuluan}

Pada penelitian ini dilakukan uji pendahuluan yang bertujuan untuk mengetahui dan menetapkan komposisi diet tinggi lemak yang mampu membuat tikus dislipidemia selama 14 hari perlakuan. Tikus dikatakan dislipidemia salah satu parameternya dapat dilihat dari penurunan kadar kolesterol HDL 
dalam darah (Ballantyne et al, 2009). Uji pendahuluan dilakukan dengan menggunakan 2 kelompok perlakuan, masing-masing terdiri dari 3 ekor hewan uji. Untuk memperkecil pengaruh variasi biologis hewan uji terhadap perbedaan hasil penelitian, maka semua hewan uji yang digunakan mempunyai jenis kelamin dan galur yang sama yaitu tikus jantan galur wistar dengan umur dan berat seragam yaitu umur 2-3 bulan, berat 100-200 g. Kelompok pertama (kontrol normal) diberikan pakan standar sedangkan kelompok kedua (kontrol negatif) diberikan diet tinggi lemak selama 14 hari. Diet tinggi lemak yang diberikan terdiri dari pakan tinggi lemak, emulsi serta pemberian PTU. Pakan tinggi lemak yang digunakan berupa pakan standar (pellet) sebanyak $300 \mathrm{~g}$ dicampur dengan $10 \mathrm{~g}$ gajih, $20 \mathrm{~g}$ kuning telur, dan $100 \mathrm{~g}$ mentega sedangkan emulsi terdiri dari $5 \mathrm{~g}$ gajih; $10 \mathrm{~g}$ kuning telur; $7,5 \mathrm{~g}$ gom arab dan air ad $100 \mathrm{ml}$. Emulsi diberikan per oral menggunakan sonde lambung dengan dosis $200 \mathrm{~mL} / 200 \mathrm{gBB}$ setiap harinya dan selalu dibuat baru.Menurut almatsier (2001) lemak sapi mengandung kolesterol sebesar $9,5 \mathrm{mg} / 10 \mathrm{~g}$ bahan, kuning telur $263 \mathrm{mg} / 10 \mathrm{~g}$ sedangkan mentega mengandung kolesterol sebesar 25mg/10g bahan (Dumadi,2002) sehinggadiharapkan dengan pemberian pakan tinggi lemak dan emulsi yang digunakan dapat diperoleh kondisi dislipidemia pada tikus, khususnya penurunan kadar HDL.

Tabel 1- Rerata Kadar HDL Sebelumdan14 Hari Setelah Diinduksi Diet Tinggi Lemak

\begin{tabular}{ccc}
\hline \multirow{2}{*}{ Kelompok } & \multicolumn{2}{c}{ Rerata Kadar HDL $(\mathrm{mg} / \mathrm{d}$ L \pm SD) } \\
& Hari ke-0 & Hari ke-14 \\
\hline Kontrol normal & $41,11 \pm 13,14$ & $36,88 \pm 6,54$ \\
Kontrol negatif & $52,54 \pm 8,91$ & $41,27 \pm 8,44$ \\
\hline
\end{tabular}

Kadar kolesterol HDL pada masingmasing kelompok perlakuan diukur pada awal dan 14 hari setelah diinduksi diet tinggi lemak. Pengukuran kadar kolesterol HDL dilakukan dengan metode enzimatik CHOD-PAP. Hasil pengukuran kadar HDL sebelum dan 14 hari setelah induksi diet tinggi lemak pada uji pendahuluan ini ditunjukkan pada Tabel1.

Berdasarkan hasil uji statistik diketahui bahwa data terdistribusi normal. Uji Unpaired $T$ test hari ke-14 menunjukkan bahwa tidak terdapat perbedaan bermakna antara kelompok kontrol normal dan kontrol negatif $(p>0,05)$. Hasil analisis dengan uji Paired $T$ test juga menunjukkan bahwa tidak terjadi penurunan kadar kolesterol HDL yang bermakna pada kelompok kontrol negatif sebelum dan 14 hari setelah diinduksi diet tinggi lemak $(p>0,05)$. Namun pada uji pendahuluan ini, telah terjadi penurunan kadar kolesterol HDL pada kelompok yang dibebani diet tinggi lemak (kontrol negatif) sebelum dan sesudah perlakuan sebesar $21,75 \%$. Berdasarkan \% penurunan kadar kolesterol HDL tersebut, maka ditarik kesimpulan bahwa komposisi diet tinggi lemak yang diberikan sudah mampu menurunkan kadar kolesterol HDL serum, namun belum dapat memberikan hasil penurunan yang bermakna dilihat dari analisis statistiknya sehingga untuk perlakuan selanjutnya komposisi diet tinggi lemak yang digunakan dapat ditingkatkan agar diperoleh penurunan kadar kolesterol HDL serum yang bermakna pada tikus jantan galur wistar.

\section{Uji Dislipidemia}

Berdasarkan pada hasil uji pendahuluan yang telah dilakukan, maka diet tinggi lemak yang diberikan pada penelitian ini ditingkatkan komposisinya. Pada penelitian ini digunakan 20 ekor hewan uji (tikus) yang dibagi menjadi 4 kelompok perlakuan dengan masing-masing kelompok terdiri dari 5 ekor hewan uji yaitu kelompok kontrol normal, kelompok kontrol negatif, kelompok dosis 1 , dan kelompok dosis 2. Semua kelompok perlakuan diukur kadar HDL pada awal dan 14 hari setelah diberi diet tinggi lemak. Rerata dan simpangan baku kadar HDL sebelum dan sesudah diberi diet tinggi lemak disajikan pada Tabel 2.

Tabel 2- Rerata Hasil Pengukuran Kadar HDL Sebelum dan 14 Hari Setelah Diberi Diet Tinggi Lemak

\begin{tabular}{cccc}
\hline Kelompok & \multicolumn{2}{c}{ Rerata kadar HDL (mg/dL \pm SD) } & Hari ke-14 \\
\hline Kontrol normal & Hari ke-0 & $31,18 \pm 8,19$ & 15,06 \\
Kontrol negatif & $38,22 \pm 7,47$ & $30,04 \pm 2,48$ & $16,35^{\star}$ \\
Dosis 1 (200 mg/kgBB) & $36,08 \pm 3,83$ & $26,48 \pm 6,39$ & $35,31^{*}$ \\
Dosis 2 (400 mg/kgBB) & $41,41 \pm 4,46$ & $23,64 \pm 5,00$ & $41,67^{*}$ \\
\hline
\end{tabular}

Keterangan : * berbeda bermakna sebelum dan setelah pemberian diet tinggi lemak $(p<0,05)$

Rerata kadar kolesterol HDL serum pada kelompok yang diberi diet tinggi lemak yaitu kelompok kontrol negatif, dosis 1 dan dosis 2 mengalami penurunan pada hari ke-14 (Tabel 2). Hasil analisis statistik menunjukkan sebaran data normal dan homogen. Hasil Anava menunjukkan tidak terdapat perbedaan bermakna antar kelompok perlakuan $(p>0,05)$. Akan tetapi, hasil analisis dengan uji Paired $T$ test menunjukkan terjadinya penurunan kadar HDL yang bermakna pada kelompok yang dibebani diet tinggi lemak sedangkan pada 
kelompok kontrol normal meskipun terjadi penurunan kadar HDL namun penurunan yang terjadi tidak menunjukkan penurunan kadar HDL yang bermakna. Agung (2008) melaporkan pemberian campuran pakan standar (pellet) dengan lemak 10\% mampu menurunkan kadar HDL secara bermakna antara sebelum dan sesudah pemberian diet tinggi lemak. Penurunan kadar kolesterol HDL secara bermakna pada tikus wistar setelah pemberian makanan tinggi lemak menunjukkan bahwa diet tinggi lemak berpengaruh terhadap kadar kolesterol HDL serum. Kolesterol HDL diproduksi oleh hati dan usus, berfungsi sebagai pengangkut kolesterol ke dalam hati (Growder et al., 2011). Pemberian diet tinggi asam lemak jenuh dapat menekan sintesis HDL melalui penurunan kadar apolipoprotein A-1 yang merupakan prekursor untuk pembentukan HDL (Eastwood et al, 1987). Pada penelitian ini air minum tikus pada kelompok kontrol negatif, dosis 1 dan dosis 2 diberi propiltiourasil (PTU). Propiltiourasil adalah zat kimia yang dapat menekan aktivitas kelenjar tiroid (Vanderpump dan Tunbridge, 2008). Kadar tiroid yang rendah akan meningkatkan kadar kolesterol dalam darah. Selain itu, pengaruh hipotiroid pada metabolisme lipoprotein adalah terjadinya peningkatan kolesterol LDL akibat penurunan jumlah reseptor LDL dan penekanan aktivitasnya (Mahajan dan Singh, 2011).

Pada penelitian ini terjadi peningkatan. berat badan tikus jantan wistar. Perubahan berat badan tersebut ditunjukkan pada Tabel 3 .

Tabel 3- Rerata Perubahan Berat Badan Tikus Tiap-tiap Kelompok Setelah 14 Hari Pemberian Diet Tinggi Lemak

\begin{tabular}{|c|c|c|c|}
\hline \multirow{2}{*}{ Kelompok } & \multicolumn{2}{|c|}{ Rerata kadar HDL (mg/dL $\pm \mathrm{SD})$} & \multirow{2}{*}{ \%penurunan } \\
\hline & Hari ke-0 & Hari ke-14 & \\
\hline Kontrol normal & $167,18 \pm 16,61$ & $204,78 \pm 45,28$ & 16,22 \\
\hline Dosis 1 (200 mg/kgBB) & $142,52 \pm 8,00$ & $200,04 \pm 25,97$ & 27,99 \\
\hline Dosis 2 (400 mg/kgBB) & $156,12 \pm 17,84$ & $207,80 \pm 19,94$ & 24,85 \\
\hline
\end{tabular}

Tabel 3 menunjukkan bahwa setelah 14 hari pemberian diet tinggi lemak berat badan tikus jantan wistar rata-rata mengalami kenaikan. Data berat badan dalam penelitian ini hanya sebagai data pelengkap dan pembanding untuk melihat sejauh mana parameter dislipidemia yaitu berat badan, terkait dengan diet standar maupun diet tinggi lemak yang diberikan pada masing-masing kelompok perlakuan. Pada kelompok kontrol normal juga mengalami peningkatan berat badan selama 14 hari perlakuan. Meskipun rata-rata asupan pakan per harinya pada kelompok kontrol normal lebih banyak, namun peningkatan berat badan yang terjadi tidak sebesar pada kelompok kontrol negatif, dosis 1 dan dosis 2 yang diberi diet tinggi lemak. Tabel 5-6 memperlihatkan peningkatan berat badan yang terjadi pada kelompok yang diberi diet tinggi lemak diikuti dengan penurunan kadar HDL yang bermakna pada masing-masing kelompok sedangkan pada kelompok kontrol normal meskipun terjadi penurunan kadar HDL akan tetapi penurunan tersebut tidak bermakna

Tabel 4- Rerata Kadar HDL Tiap-tiap Kelompok Setelah Pemberian Ekstrak Etanol Jamur Lingzhi

\begin{tabular}{ccc}
\hline \multirow{2}{*}{ Kelompok } & \multicolumn{2}{c}{$\begin{array}{c}\text { Rerata Kadar HDL } \\
(\mathrm{mg} / \mathrm{d} \mathrm{L} \pm \mathrm{SD})\end{array}$} \\
& Hari ke-14 & Hari ke-28 \\
\hline Kontrol normal & $31,18 \pm 8,19$ & $33,37 \pm 4,62$ \\
Kontrol negatif & $30,04 \pm 2,48$ & $22,81 \pm 5,53$ \\
Dosis 1 (200mg/kgBB) & $26,48 \pm 6,39$ & $29,58 \pm 5,55$ \\
Dosis 2 (400mg/kgBB) & $23,64 \pm 5,00$ & $31,72 \pm 7,96$ \\
\hline Keterangan: (-) terjadi & penurunan kadar $\mathrm{HDL} ;(+)$ terjadi \\
peningkatan kadar HDL
\end{tabular}

secara statistik. Menurut Ahmed et al (1998) kegemukan (obesitas) akibat asupan tinggi lemak berlebih dapat menjadi penyebab sekunder terjadinya penurunan kadar HDL dalam darah.

Pada keadaan normal tubuh dapat mempertahankan keseimbangan kolesterol melalui mekanisme penghambatan umpan balik dengan cara kolesterol sel menghambat biosintesis kolesterol baru. Apabila kadar kolesterol darah meningkat,kolesterol akan menghambat biosintesisnya dengan cara menghambat aktivitas HMG-KoA reduktase (Hiroksi-Metil-Glutaril-koA reduktase) yaitu enzim yang mengontrol tahap pembatas kecepatan pada sintesis kolesterol (Murray, 2002). Diet tinggi lemak berlebih mengakibatkan enzim HMG-KoA reduktase ini tidak dapat menjalankan fungsinya secara maksimal, dengan demikian kelebihan lemak akan disimpan dalam jaringan adipose yang berperan dalam peningkatan berat badan tikus (Ahmed \& Olfat, 2010).

\section{Hasil Pengujian Ekstrak Etanol Jamur Lingzhi Terhadap Kadar HDL}

Penelitian ini bertujuan untuk mengetahui efek peningkatan kadar kolesterol HDL pada tikus dislipidemia yang diberi ekstrak etanol jamur lingzhi (Ganoderma lucidum) selama 14 hari perlakuan. Ekstrak etanol jamur lingzhi yang diberikan pada hewan uji (tikus) dibagi dalam2 dosis yaitu dosis200mg/kgBB (dosis 1) dan $400 \mathrm{mg} / \mathrm{kgBB}$ (dosis 2). Pemberian pada dosis yang berbeda ditujukan untuk mengetahui 
pada dosis berapa ekstrak etanol jamur lingzhi dapat memberikan efek hipokolesterolemia yang optimal dilihat dari peningkatan kadar HDL. Pemberian diet tinggi lemak pada kelompok kontrol negatif, dosis 1 dan dosis 2 tetap dilanjutkan sampai hari ke-28. Data hasil pengukuran kadar kolesterol HDL setelah diberi ekstrak etanol jamur lingzhi dapat dilihat pada tabel 4.Dari tabel 4. diketahui bahwa pada kelompok kontrol negatif tetap mengalami penurunan kadar HDL secara bermakna sampai hari ke-28 sedangkan kelompok yang diberi ekstrak etanol jamur lingzhi dosis $200 \mathrm{mg} / \mathrm{kgBB}$ dan $400 \mathrm{mg} / \mathrm{kgBB}$ mengalami peningkatan kadar HDL. Hal ini menunjukkan bahwa ekstrak etanol jamur lingzhi (Ganoderma lucidum) mampu menghambat penurunan kadar HDL dalam darah. Perubahan kadar HDL selama 28 hari perlakuan dapat dilihat jelas pada

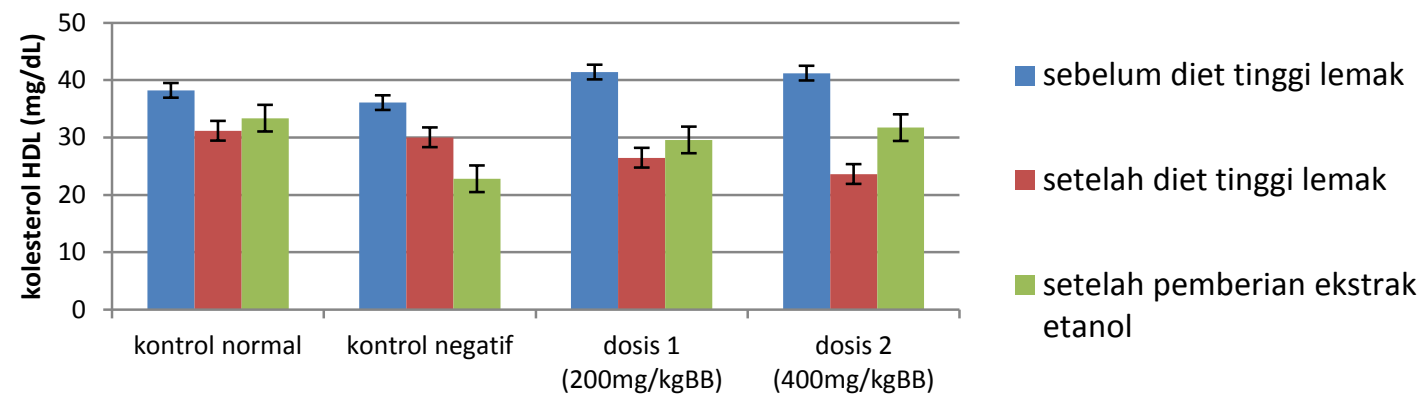

Gambar 1- Diagram perbandingan kadar HDL selama 28 hari perlakuan

Hasil analisis Anava antara kelompok yang diberi ekstrak etanol jamur lingzhi dengan kelompok kontrol negatif menunjukkan bahwa peningkatan kadar HDL yang terjadi setelah pemberian ekstrak etanol jamur lingzhi dosis $200 \mathrm{mg} / \mathrm{kgBB}$ dan dosis $400 \mathrm{mg} / \mathrm{kgBB}$ tidak signifikan $(p>0,05)$. Meskipun secara statistik tidak terjadi kenaikan yang bermakna, namun terlihat adanya kecenderungan peningkatan kadar HDL darah masing-masing sebesar $22,89 \%$ dan 28,09\% dibandingkan kontrol negatif. Hal ini kemungkinan disebabkan oleh penggunaan dosis yang terlalu kecil sehingga belum dapat memberikan efek peningkatan kadar HDL yang bermakna pada tikus jantan wistar. Efek peningkatan HDL pada tikus dislipidemia yang diberi ekstrak etanol jamur lingzhi ini berbeda dengan penelitian yang dilakukan oleh Yang et al (2002). Hasil penelitian tersebut menunjukkan bahwa pemberian biopolymer Ganoderma lucidum dosis $100 \mathrm{mg} / \mathrm{kgBB}$ selama 4 minggu mampu meningkatkan kadar HDL secara bermakna dibandingkan kontrol negatifnya pada tikus hiperlipidemia.

Menurut Boh et al (2007) senyawa triterpenoid yang terkandung dalam jamur lingzhi (Ganoderma lucidum) memiliki efek hipokolesterolemia. Jia et al (2011) menyebutkanbahwa mekanisme hipokolesterolemia senyawa golongan triterpenoid melalui aktivasi PPAR- $\alpha$ yang mengatur ekspresi gen metabolisme lipid. Selain itu, Goto et al (2010) juga melaporkan bahwa senyawa terpenoid merupakan ligan bagi PPAR (peroxisome proliferator-activated receptor). Sebagian besar sintesis
apolipoprotein-A1 yang merupakan prekursor pembentukan HDL diatur oleh PPAR- $\alpha$ sehingga aktivasi PPAR-a langsung dapat berkontribusi untuk peningkatan apolipoproteinA1 dan akhirnya akan meningkatkan kadar HDL dalam darah. Mekanisme kerja triterpenoid dalam meningkatkan kadar HDL mirip dengan Fibrat. Derivat asam fibrat meningkatkan kadar HDL dengan cara mengaktifkan PPAR- $\alpha$ (Francis et al, 2003).

Kolesterol HDL mempunyai peranan yang penting pada keadaan dislipidemia sehingga kadarnya di dalam darah dapat dijadikan salah satu sasaran terapi penderita dislipidemia. Pada kondisi dislipidemia, membran sel jenuh terhadap kolesterol karena penerimaan LDL dan biosintesis internal yang berlebih. Peran penting HDL dalam tubuh untuk melakukan penyeimbangan kolesterol melalui transpor kolesterol terbalik (reverse cholesterol transport) dengan mengambil kelebihan kolesterol di jaringan dan membawanya ke hati untuk selanjutnya diproses dan diekskresikan sebagai garam empedu (Murray et al, 2009). Tidak hanya itu, kolesterol HDL juga berperan dalam menghambat terjadinya ateroklerosis dengan cara melindungi kolesterol LDL dari proses oksidasi (Barter, 2005).

\section{KESIMPULAN}

Berdasarkan penelitian yang telah dilakukan didapatkan hasil bahwa ekstrak etanol jamur lingzhi (Ganoderma lucidum) dosis $200 \mathrm{mg} / \mathrm{kgBB}$ dan $400 \mathrm{mg} / \mathrm{kgBB}$ tidak mampu meningkatkan kadar HDL pada tikus dislipidemia. 


\section{SARAN}

1. Sebaiknya dilakukan pengukuran kadar lipid yang lain seperti kadar kolesterol total, dan kolesterol LDL sehingga dapat diketahui apakah diet tinggi lemak yang diberikan mempengaruhi kadar kolesterol total dan kolesterol LDL.
2. Mengacu pada hasil penelitian ini, untuk memperoleh peningkatan kadar HDL yang bermakna perlu dilakukan penelitian lebih lanjut dengan peningkatan dosis dan dapat ditambah kontrol positif seperti derivat asam fibrat untuk membandingkan efektivitas peningkatan kadar HDL diantara keduanya.

\section{DAFTAR PUSTAKA}

Agung, V., 2008, Pengaruh Pemberian Ekstrak Daun Salam (Eugenia polyantha) Terhadap Kadar HDL Kolesterol Serum Tikus Jantan Galur Wistar Hiperlipidemia, Fakultas Kedokteran, Unversitas Diponegoro Semarang.

Ahmed, M.S., Clusen, M.E. \& Donnelly, J.F., 1998, Management of Dyslipidemia in Adults, AM Fam Physician, 57(9), 2192-2204.

Ahmed, M.S. \& Olfat, M.Y., 2010, Physiological Responsible for Aterosclerotic in Rat, Nature and Science, 8(5), 144-155.

Almatsier, S., 2001, Prisnsip Dasar Ilmu Gizi, 66-68, Gramedia Utama, Jakarta.

Ballantyne, C.M., O'keefe, J.H. \& Gotto, A.M., 2009, Dyslipidemia \& Atherosclerosis Essentials, 56 , John and Bartlett Publiser, London.

Barter, P., 2005, The Role of HDL-Cholesterol in Preventing Atherosclerotic Disease, European Heart Journal Supplements, 7, F4-F8.

Boh, B., Berovic, M., Zhang, J. \& Zhi-Bin, L., 2007, Ganoderma lucidum and its pharmaceutically active compounds, (online), (http://www.ncbi.nlm.nih.gov/pubmed/17875480, diakses 20 Mei 2011)

Chen, W.Q., Luo, S.H., Li, H.Z. \& Yang, H., 2005, Effects of Ganoderma lucidum Polysaccharides on Serum Lipids and Lipoperoxidation in Experimental Hyperlipidemic Rats, (online), (http://www.ncbi.nlm.nih.gov/pubmed/16323548, diakses 4 mei 2011).

Dumadi, S.R., 2002, Resiko Kolesterol Darah dan Diet Lemak, Jurnal Farmasi Pancasila, 1(1), 915.

Eastwood, M., Edwards, C. \& Pery, D., 1987, Human nutrition, 33-65, Chapman \& Hall, London.

Francis, G.A., Annicotte, J.S. \& Auwerx, J., 2003, PPAR- a effects on the heart and other vascular tissues, Am J Physiol Heart Circ Physiol, 285, H1-H9.

Goto, T., Takahashi, H., Hirai, S. \& Kawada, T., 2010, Various Terpenoids Derived from Herbal and Dietary Plants Function as PPAR Modulators and Regulate Carbohydrate and Lipid Metabolism, PPAR Research, 1-9.

Growder, D.M., Riley, C., Morisson, E.Y.S.A. \& Gordon, L., 2011, The Role of High-Density Lipoproteins in Reducing the Risk of Vascular Diseases, Neurogenerative Disorders, and cancer, (online), (http://www.hindawi.com/journal/chol/2011/496925, diakses 20 Mei 2011)

Hayati, E.K. \& Halimah, N., 2010, Phytochemical Test and Brine Shrimp Lethality Test Against Artemia salina Leach of Anting-anting (Acalypha indica Linn.) Plant Extract, Alchemy, 1(2), 53-103.

Jia, Y., Jun, H.J., Lee, J.H., Hoang, M.H., Lee, H.J., Kim, N., Lee, D., Hwang, K.Y., Hwang, B.Y., Choi, D.W. \& Lee, S.J., 2011, Ursolic acid is a PPAR- $\alpha$ agonist that regulates hepatic lipid metabolism, (online), (http://www.ncbi.nlm.nih.gov/pubmed/21855333, diakses 27 januari 2012)

Kotsner, K.., 2002, LDL-Cholesterol: New Treatments Raising HDL Cholesterol or Enhancing Reverse Cholesterol Transport, Journal of Cardiology, 9 (7-8), 328-331. 
Mahajan, R.D. \& Singh, R., 2011, Thyroid dysfunction and total cholesterol - experience in a tertiary care hospital, Research Journal of Pharmaceutical, Biological and Chemical Sciences, 2(2), 268-273.

Murray, K., 2002, Harper Biochemestry, twenty fifth ed., Mc Graw Hill Companie, New York.

Murray, K., 2009, Biokomia Herper, Edisi dua puluh tujuh, diterjemahkan oleh Pendit, B.U., 240249, EGC, Jakarta.

Paterson, R.R.M., 2006, Ganoderma: A Therapheutic Fungal Biofactory, Phytochemistry, 67, 19852001.

Pinzon, R. \& Asanti, L., 2010, AWAS STROKE! Pengertian, Gejala, Tindakan, Perawatan dan Pencegahan, Edisi pertama, 10-11, Andi,Yogyakarta.

Sidhi, P., 1991, Perbandingan Penetapan Kadar Kolesterol Metode CHOD-PAP, Fakultas Kedokteran Universitas Gajah Mada, Yogyakarta.

Suyatna, F.D., 2008, Farmakologi dan Terapi, Edisi kelima, 374-385, Departemen Farmakologi dan Terapeutik Fakultas Kedokteran UI, Jakarta.

Vanderpump, M.P.J. \& Tunbridge, W.M.G., 2008, Thyroid Disease, fourth ed., Oxford University Press, New York.

Williamson, M.E., Okpako, T.D. \& Evans, J.E., 1996, Selection, Preparation, and Pharmacological Evaluation of Plant Material, 19, John Wiley and Son Ltd, England..

Yang., Keun, B., Jeong, S.C. \& Song, C.H., 2002, Hypolipidemic Effect of Exo- and EndoBiopolymer Produced from Submerged Mycelial Culture of Ganoderma lucidum in Rats, Journal of Microbiology and Biotechnology, 12(6), 872-877. 